\title{
Effect of a Brief Education on the Occupational History Taking in Hypertension Patients
}

Seval Müzeyyen Ecin*, [MD]

Adem Koyuncu ${ }^{1},[\mathrm{MD}]$

Abdulsamet Sandal ${ }^{1},[\mathrm{MD}]$

Sultan Pınar Çetintepe ${ }^{1}$, [MD]

Nursel Çalık Başaran², [MD]

Şerife Gül Öz ${ }^{3}$, [MD]

Ali Naci Yildiz ${ }^{4}$, [MD]

${ }^{1}$ Hacettepe University, Faculty of Medicine, Department of Internal Medicine, Unit of Occupational Medicine, Ankara, Turkey

${ }^{2}$ Hacettepe University, Faculty of Medicine, Department of Internal Medicine, Unit of General Internal Medicine, Ankara, Asistant Professor

${ }^{3}$ Hacettepe University, Faculty of Medicine, Department of Internal Medicine, Unit of General Internal Medicine, Ankara, Professor

${ }^{4}$ Hacettepe University, Faculty of Medicine, Department of Public Health, Ankara, Professor

*Corresponding Author: Seval Müzeyyen Ecin. Hacettepe University, Faculty of Medicine, Department of Internal Medicine, Unit of Occupational Medicine, Ankara, Turkey

E-mail: muzeyyenecin@hacettepe.edu.tr

Phone: 0312- 3053426

DOI: https://doi.org/10.32552/2018.ActaMedica.332

\section{reQ ABSTRACT Ceen}

Objective: This study is designed to measure the effect of 10-minutes training about occupational diseases, history taking and relation of occupation and hypertension on occupational history taking rates of physicians.

Materials and Methods: This research is conducted between 01 April 2018 to 31 May 2018 at Hacettepe University Faculty of Medicine, Department of Internal Medicine, Division of General Internal Medicine Outpatient Clinic. The training including the importance and methods of taking occupational history, and the relation between occupation and diseases is given to the new assistant doctor group as an extra 10 minutes' education session. At the end of May, researchers screened electronic medical files of patients who diagnosed with hypertension (ICD10 code I10) of outpatients in General Internal Medicine Division in April and May 2018.

Results: We reviewed the data of 3619 adult patients administered to General Internal Medicine Outpatient Clinic of Hacettepe University Hospitals in between 01 April to 31 May 2018. A total of 395 (10.9\%) patients had hypertension diagnosis code. The total number of patients whose occupational history taken were 151 (38.2\%). There were statistically significant difference between physician groups not trained in April and trained 10 minutes in May, 62 (32\%), and 89 (44.3\%), respectively (p:0.012). Among the hypertensive patients whose occupational history were recorded, 36 (23.8\%) had an occupation.

Conclusion: This result emphasizes the importance of education in raising awareness of taking an occupational history. As occupational diseases are $100 \%$ preventable diseases, taking occupational history will enhance the diagnosis and effective treatment of the occupational or work-related diseases. Beginning from the medical faculty lectures, seminars and post-graduate education have to be added and increased regarding this important issue.

Keywords: Occupational history, occupational disease, hypertension.

\section{INTRODUCTION}

Occupational diseases, according to the World Health Organization (WHO), are the common name for the diseases which is affected by the factors in the workplace environment [1]. Turkish Social Insurances and General Health Insurance Law (5510), Article 14 is defined as "Occupational disease is temporary or permanent illness and physical or mental disability caused by a repeated reason due to the nature of the work or work conditions" [2].

Occupational history is one of the mainstay of diagnosis in occupational diseases and must be taken to evaluate the contribution of work life to the development of diseases. Five fundamental questions were designed to evaluate the association between occupation and any symptom or disease. These questions are: 1. Are you working? If yes what is your 
occupation? 2. Do you think your health problem is related to your occupation? 3. Are your symptoms changing due to your environment (workplace or house)? 4. Have you ever been exposed to chemical agents, radiation, dust, noise, extreme hot or cold at your workplace? 5. Does any of your colleagues have the same symptoms that you had? [3]. If one or more of these questions reveal any relation, then detailed occupational history must be taken for definitive diagnosis [4]. It has been shown in a variety of studies that taking occupational history and asking about occupation and exposure is very low during daily practice in patient examinations $[5,6,7]$. One of the most important reason is the lack of knowledge of physicians in establishing relationship between diseases and occupation and taking occupational history. In this study, we aimed to measure the effect of a brief information in about diseases and occupational aspect and key questions in occupational history on physicians. And due to high prevalence in the population and occupational relation, we focused on hypertensive patients. We think that the occupation and working life are not questioned in detail among patients having primary hypertension.

Hypertension is defined as systolic blood pressure $\geq 140 \mathrm{mmHg}$ and / or diastolic blood pressure $\geq 90 \mathrm{mmHg}[8,9]$ and affects $35-46 \%$ of population. Beside high incidence and prevalence, hypertension also is one of the leading cause of mortality and morbidity in adults. Hypertension is classified as primary (essential) and secondary hypertension. Primary hypertension is $\sim 95 \%$ of all hypertension cases. Secondary hypertension is defined as hypertension due to an underlying and possibly reversible medical condition, constitutes $\sim 5 \%$ of all hypertension cases [10]. Hypertension is also the most common cardiovascular disease with $15-20 \%$ rate of the working people [4].

Physical, chemical and psychosocial factors can cause hypertension in working life. Noise from physical factors is considered a stress source that causes psychosocial, hormonal changes and peripheral vasoconstriction [4]. In extreme cold conditions, vasoconstriction occurs in the veins and can cause hypertension. The response mechanisms of the cardiovascular system have not yet been elucidated by exposure to full body vibration. Heavy workload can lead to blood pressure elevation through increased metabolism and heart rate [11]. Various chemicals exposed during work can affect blood pressure. It has been shown that heavy metals such as lead, mercury, aluminum, arsenic and nickel; solvents such as hydrocarbons, aliphatic nitro compounds, inorganic sulfur compounds, aromatic amino compounds can increase blood pressure and cause hypertension [12,13]. Chronic psychological stress from psychosocial factors were found to increase the adrenaline and noradrenalin levels in the activation of sympathetic adrenomedullary axis and circulation [4].

This study is designed to measure the effect of 10-minutes training about occupational diseases, history taking and relation of occupation and hypertension on occupational history taking rates of physicians

\section{MATERIALS and METHODS}

This research is conducted between 01 April 2018 to 31 May 2018 at Hacettepe University Faculty of Medicine, Department of Internal Medicine, Division of General Internal Medicine Outpatient Clinic. First day of each month, assistant doctors who examine patients throughout a month change and take theoretical training on practice of clinic. The training including the importance and methods of taking occupational history, and the relation between occupation and diseases is given to the new assistant doctor group as an extra 10 minutes' education session. In addition, they were informed for the observation of the occupational history ratios after this training. The difference of taking occupational history of hypertensive patients searched between two, trained and non-trained, physician groups. At the end of May, researchers screened electronic medical files of patients who diagnosed with hypertension (ICD10 code I10) of outpatients in General Internal Medicine Division in April and May 2018. Sociodemographic data, diagnosis time of hypertension, treatment status, accompanying chronic diseases, occupational history, exposures in workplace were collected from these medical files. Local ethical committee approved this trial.

\section{Statistical Analysis}

The Statistical Package for Social Sciences software (SPSS 22, Inc., Chicago, IL, USA) was used for statistical analysis. Descriptive statistics were given as frequency ( $\mathrm{n}$ ) and percentage (\%) for nonparametric and as mean \pm Standard Deviation $( \pm$ SD) for normally distributing parametric data. We used chisquare tests to compare categorical variables. The significance level was set at the $5 \%$ value. 


\section{RESULTS}

We reviewed the data of 3619 adult patients (19-65 years old) patients administered to General Internal Medicine Outpatient Clinic of Hacettepe University Hospitals in between 01 April to 31 May 2018. A total of 395 (10.9\%) patients had hypertension diagnosis code; 194 (49.1\%) patients were admitted in April and 201 (50.9\%) in May. The mean age was 54.7 7.75 years and 275 (69.6\%) were female. The 317 (80.3\%) of hypertensive patients had at least one chronic disease. The demographic data and distribution of the diseases are given in Table1.

Table 1. The demographic data and distribution of comorbid diseases of the patients with hypertension ICD10 code.

\begin{tabular}{|c|c|}
\hline Total Number, n (\%) & 395 \\
\hline $\begin{array}{l}\text { Gender, } \\
\text { Female } \\
\text { Male }\end{array}$ & $\begin{array}{l}275(69.6) \\
120(30.4)\end{array}$ \\
\hline Age, Mean \pm Standard Deviation $( \pm$ SD) & $54.7 \pm 7.75$ years \\
\hline $\begin{array}{l}\text { Age groups (years) } \\
21-49 \\
50-59 \\
60-65\end{array}$ & $\begin{array}{l}81(20.5) \\
202(51.1) \\
112(28.4)\end{array}$ \\
\hline $\begin{array}{l}\text { Comorbid Diseases } \\
\text { Yes } \\
\text { No } \\
\text { Distribution of comorbid diseases* } \\
\text { Diabetes mellitus } \\
\text { Hypothyroidism } \\
\text { Hyperlipidemia } \\
\text { Coronary artery diseases } \\
\text { Respiratory system diseases ** } \\
\text { Gastrointestinal system disease } \\
\text { B12 deficiency } \\
\text { Vitamin D deficiency } \\
\text { Other diseases }\end{array}$ & $\begin{array}{c} \\
164(51.7) \\
82(25.9) \\
77(24.3) \\
41(12.9) \\
34(10.7) \\
24(7.6) \\
4(1.3) \\
4(1.3) \\
89(28.1)\end{array}$ \\
\hline
\end{tabular}

* The patients has more than one chronic disease so the total number of comorbid diseases is higher than 317.

**Respiratory system diseases include asthma, chronic obstructive lung disease

***Other diseases include hematologic, rheumatologic, renal diseases

Three hundred forty patients (86.1\%) were already hypertensive and the mean duration of hypertension was 10.1 \pm 7.2 years. Medication was prescribed to $36 / 55$ (65.4\%) of newly diagnosed hypertensive patients, the rest only lifestyle changes were recommended. Number of previously diagnosed patients with hypertension was 340 (86.1\%) and 55 (13.9\%) new diagnosed number was 55 (13.9\%). Among previously diagnosed patients 305 (89.7\%) were using at least one antihypertensive drug.

The total number of patients whose occupational history taken were 151 (38.2\%). The rates according to trained and non-trained groups are presented in Table 2. There were statistically significant difference between physician groups not trained in April and trained 10 minutes in May, 62 (32\%), and $89(44.3 \%)$, respectively ( $\mathrm{p}: 0.012)$.

Among the hypertensive patients whose occupational 
Table 2. Distribution of occupational history taking according to trained and not-trained groups.

\begin{tabular}{|c|c|c|c|c|c|c|}
\hline \multirow[t]{2}{*}{ Physician group } & \multicolumn{4}{|c|}{ Occupational History } & Total & $P$ value \\
\hline & Yes (N) & Percent \% & No $(\mathrm{N})$ & Percent \% & Number & \multirow{3}{*}{0.012} \\
\hline Not-trained & 62 & 32.0 & 132 & 68.0 & 194 & \\
\hline Trained & 89 & 44.3 & 112 & 55.7 & 201 & \\
\hline
\end{tabular}

history were recorded, 36 (23.8\%) had an occupation (Table 3). Occupational risk factors for hypertension has been asked only $9 / 151$ (6\%) of the hypertensive patients; 7 patients did not declared any risk factor such as noise, work stress, cold, chemicals, where 1 patient had work stress, and 1 patient had unknown chemical exposure

Table 3. Occupational distribution of hypertension patients.

\begin{tabular}{|l|c|c|}
\hline Occupational(N=151) & Number & Percent \% \\
\hline Housewife & 77 & 50.9 \\
\hline Retired & 27 & 17.8 \\
\hline Officer & 22 & 16.75 \\
\hline Worker & 8 & 5.29 \\
\hline Not working & 8 & 5.29 \\
\hline Self-employee & 6 & 3.97 \\
\hline Total & 151 & 100.0 \\
\hline
\end{tabular}

\section{DISCUSSION}

In various studies in Turkey the prevalence of hypertension in the adult group was 30.3-35.9 \% [10,14]. Prevalence in the $30-39$ age group is $19 \% ; 36.1 \%$ in females and $27.7 \%$ in males [1]. In our study, hypertension was present in $10.6 \%$ of the patients with female predominance. Our study is not designed to search hypertension prevalence, and the patients admitting to outpatient clinic with various reasons cannot reflect general population. The prevalence of hypertension in patients with diabetes mellitus is about $50 \%$. Also in our study, the most comorbid disease in hypertension was also diabetes mellitus (51.3\%) and similar to the literature.

A study in Britain showed that $75 \%$ of family physicians took occupational history, and another study from Turkey $56.1 \%$ of outpatient clinic physicians took occupational $[5,6]$. Another study in Turkey showed that $89.7 \%$ of physicians didn't take occupational history [7]. In our study we found that only $38.2 \%$ of the hypertensive patients' occupational history were taken. This situation is similar to other researches from Turkey but lower than developed countries. The importance and awareness of occupational disease and work related disease is not enough. And that the relationship between diseases and occupation cannot be established adequately. In Bangladesh, Islam at all showed that prevalence of hypertension was high in housewives (34.1\%) [15]. Our findings also declared that the most frequent occupational risk group for hypertension was housewives (50.9\%).

In this study, we added extra 10 minutes training including the importance and methods of taking occupational history to physicians who will work in outpatient clinic in May 2018 on the first day of that month. And we found that either a brief training increased the rate of taking occupational history significantly ( $p: 0.012)$. This result emphasizes the importance of education in raising awareness of taking an occupational history. As occupational diseases are $100 \%$ preventable diseases, taking occupational history will enhance the diagnosis and effective treatment of the occupational or work-related diseases.

Even if a patient is diagnosed correctly and treatment is given, if the occupational relationship cannot be established, the patient's exact treatment will not be possible because the occupational exposure will continue as long as the patient continues to work. Another and very important point is 
that it is possible to determine the diseases of the colleagues who are exposed to the same effect as the patient and to take the necessary precautions for primary prevention. Beginning from the medical faculty lectures, seminars and post-graduate education have to be added and increased regarding this important issue.

\section{CONFLICT of INTEREST STATEMENT}

The authors declare they have no conflicts of interest.
[1] WHO. Occupational and work related diseases. http://www who.int/occupational_health/activities/occupational_work_ diseases/en/ (accessed March 2018)

[2] 5510 Sayılı Sosyal Sigortalar ve Genel Sağlık Sigortası Kanunu. T. C. Resmi Gazete Tarihi: 16.6.2006, Resmi Gazete Sayısı: 26200.

[3] Bilir N, Yıldız AN. Meslek hastalığı kavramı. İş sağlığı ve güvenliği. 2. Ed. Ankara; Hacettepe Üniversitesi Yayınları, 2013:189-215

[4] Alagüney ME, Öz ŞG. Meslek Hastalıkları İşle Illgili Hastalıklar. Çalışma Hayatı ve Hipertansiyon. Yıldız Al, Sandal A. Ed. Ankara; Hacettepe Üniversitesi Yayınları, 2018: 127-135

[5] Elms J, O'Hara R, Pickvance S, et al. The perceptions of occupational health in primary care, Occupational Medicine 2005; 55: 523-527.

[6] Çimrin AH, Sevinc C, Kundak I, et al. Attitudes Of Medical Faculty Physicians About Taking Occupational History. Medical Education 1993; 33: 466-467.

[7] Pınar T, Çakmak A Z, Saygun M, et al. Hasta Dosyalarında Tanı ve Tedaviyi Etkileyebilecek Meslek Vve Diğer Faktörlerin Tıbbi Kayıtlarda Yer Alma Durumlarının Değerlendirilmesi. Turkiye Klinikleri J Med Sci, 2008; 28: 40-47.

[8] Bell K, Twiggs J, Bernie R, et al. Hypertension: The Silent Killer: Updated JNC-8 Guideline Recommendations. Alabama Pharmacy association, 2015; p. 1-8.

[9] Williams B, Mancia G, Spiering W, et al. 2018 ESC/ESH Guidelines for the management of arterial hypertension: The
Task Force for the management of arterial hypertension of the European Society of Cardiology and the European Society of Hypertension: The Task Force for the management of arterial hypertension of the European Society of Cardiology and the European Society of Hypertension. J Hypertens 2018; 36(10): 1953-2041. doi: 10.1097/HJH.0000000000001940

[10] Hipertansiyon Tanı ve Tedavi Kılavuzu, Türkiye Endokrinoloji ve Metabolizma Derneği, 2018. http://temd.org.tr/admin/uploads/tbl_kilavuz/20180518104908-2018-05-18tbl_ kilavuz104905.pdf (accessed November 2018)

[11] Work and Hypertension, Occupational Safety and Health Branch Labor Departmant. https://www.labour.gov.hk/eng/ public/oh/WorkAndHypertension.pdf (accessed November 2018)

[12] Aneni EC, Escolar E, Lamas GA. Chronic Toxic Metal Exposure and Cardiovascular Disease: Mechanisms of Risk and Emerging Role of Chelation Therapy. Curr Atheroscler Rep. 2016; 18(12): 81.

[13] International Labor Office (ILO). Encyclopedia of Occupational Health and Safety. 4th Ed. ILO, 1998.

[14] Arıcı M, Birdane A, Güler K, et al. Türk Hipertansiyon Uzlaşı Raporu. Türk Kardiyol Dern Arş - Arch Turk Soc Cardiol 2015; 43(4): 402-409,

[15] Islam, SMS, Mainuddin AKM, Serajul MD, et al. Prevalence of Risk Factors for Hypertension: A Cross-Sectional Study in an Urban Area of Bangladesh. Global Cardiology Science and Practicem 2015; 2015(4): 43. 